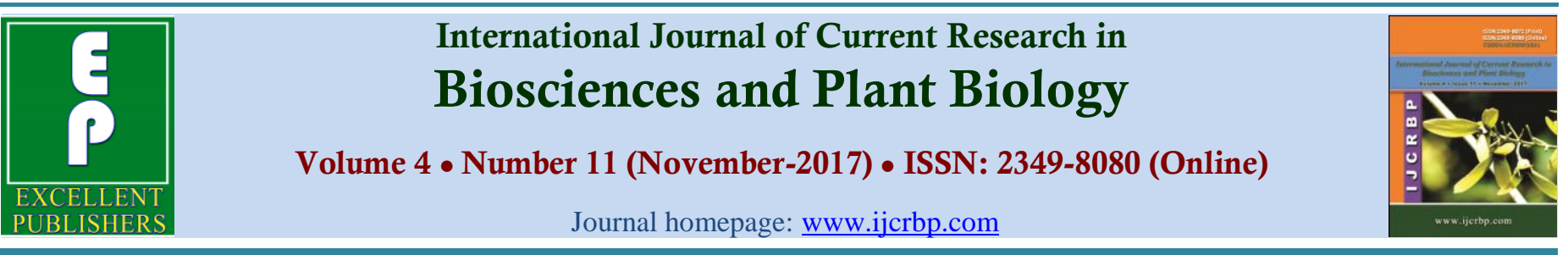

\title{
Effects of Potassium Fertilizer on the Growth and Physiology of Phoebe bournei Seedlings
}

\author{
Sijia Zhu and Gang Liu*
}

Germplasm Resources Evaluation and Innovation Center of Phoebe Yangtze University, Jingzhou-434025, Hubei, China

*Corresponding author.

\begin{tabular}{|c|c|}
\hline Abstract & Article Info \\
\hline \multirow{3}{*}{$\begin{array}{l}\text { With a potted field experiment, this paper studied the effects of potassium fertilizer on the } \\
\text { growth and physiological of Phoebe bournei seedlings, which in order to provide basis for } \\
\text { the cultivation and application of Phoebe bournei seedlings. With the increase of } \\
\text { potassium, the results showed that base diameter, leaf length, leaf width, root fresh weight } \\
\text { and root dry weight increased first and decreased afterwards and seedling height } \\
\text { increased; the net photosynthetic rate (Pn), stomatal conductance (Gs), intercellular } \mathrm{CO}_{2} \\
\text { concentration }\left(\mathrm{C}_{\mathrm{i}}\right) \text { and transpiration rate (Tr) increased first and decreased afterwards and } \\
\text { reached the highest level under A4, content of MDA decreased first and then increased } \\
\text { and reached the lowest level under A4, and the soluble sugar content increased. As a } \\
\text { result, the optimal potassium can promote photosynthesis and morphological growth of } \\
\text { Phoebe bournei seedlings, and enhanced stress protection under stress, the optimum } \\
\text { fertilizer ratio was } \mathrm{N}+\mathrm{P}+\mathrm{K}=150 \mathrm{mg}+22.5 \mathrm{mg}+450 \mathrm{mg} \text { (A4) in the seedling growth of } \\
\text { Phoebe bournei. }\end{array}$} & $\begin{array}{l}\text { Accepted: } 20 \text { October } 2017 \\
\text { Available Online: } 06 \text { November } 2017\end{array}$ \\
\hline & Keywords \\
\hline & $\begin{array}{l}\text { Growth } \\
\text { Phoebe bournei } \\
\text { Physiological ecology } \\
\text { Potassium fertilizer }\end{array}$ \\
\hline
\end{tabular}

\section{Introduction}

Phoebe bournei is rare and precious tree of Lauraceae family in China, which is listed as secondary key protecting plants of an endangered species (Fu and Jin, 1991). Furthermore, Phoebe bournei is well-known of straight trunks, plump crown and beautiful shape for courtyard appreciation and urban greening tree species, which distributed mainly in evergreen broad-leaved forest of an altitude of 200-1000m in Zhejiang, Fujian, Jiangxi, Guangdong, Guizhou and other places. While it's wild resources is decreasing with the excessive deforestation in recent years. The problem of material short can be solved radically and wildness resource can be protected efficiently by cultivating seedlings and cultivating artificial forestry scaling, which proposed by some scholars as early as 1976 (Zhou et al., 1976). At present, the physiological ecology (Wu, 1995; Wu and Wang, 2001), afforestation technology (Chu et al., 2014), seedling cultivation (Wu et al., 2015), genetic improvement (Li, 2013) of Phoebe bournei has been studied widely. For example, it has been realized that the optimum phosphorus supply for single Phoebe bournei seedling was $100-150 \mathrm{mg}$ and the optimum nitrogen supply was $22.5-30 \mathrm{mg}$ (Wang et al., 2013; Wang et al., 2014). While we found that seedlings introduced from Fujian was hard to resist low temperature, following yellowing top leaf and even whole dead plant. It's necessary to solve this problem to provide convenience for seedling cultivation. Then we found that the freezing 
damage of Phoebe bournei seedlings under better nutrient condition was lighter. As a result, we presumed that potassium played a key role through the soil analysis of Phoebe bournei. In plant growth and development, potassium is essential and can promote absorption of trace element and other major element, particularly nitrogen and phosphorus (Liu et al., 2015).

In addition, potassium can improve photosynthetic efficiency and is also an activator of many enzymes (Huang et al., 2012). However, it's not more the better about potassium application, which can significantly improve the growth of plants with the increase of potassium supply within a certain range and can inhibit when it exceeds a certain level (Guan et al., 2014). In this study, we aimed to explore the effects of growth, photosynthetic physiology and cold resistance of Phoebe bournei seedlings under different ratio of nitrogen, phosphorus and potassium, which in order to provide theoretical basis for scientific fertilization and cold resistance of Phoebe bournei seedlings.

\section{Materials and methods}

\section{Plant materials}

A total of 180 pot three years bare root Phoebe bournei seedlings with the diameter of $4.55 \pm 0.1 \mathrm{~mm}$ and the height of $42 \pm 0.6 \mathrm{~cm}$ were selected from open field. And the seedlings were transplanted to plastic basin, and transferred to botanical garden with a canopy density of $82 \%$ for centralized management and normal water management. Potting mixture was evenly mixed by river sand, perlite, ceramsite and peat according to the ratio of 20:10:5:1 and sterilized with carbendazim. The upper diameter of the plastic basin is $21 \mathrm{~cm}$, and the lower caliber is $15 \mathrm{~cm}$, and the height is $18 \mathrm{~cm}$. It is worth noting that total quality of seedlings, plastic basin and potting mixture was four kilograms.

\section{Experimental design}

A total of 150 pot Phoebe bournei seedlings were divided into five groups, which possessed consistent growth and obvious bud germination. And once fertilizer every two weeks, sum to 6 times. The fertilizer treatment for single plant was divided into 5 gradients (A1-A5), A1: $\mathrm{N}+\mathrm{P}+\mathrm{K}=150 \mathrm{mg}+22.5 \mathrm{mg}+0 \mathrm{mg}, \quad \mathrm{A} 2$ : $\mathrm{N}+\mathrm{P}+\mathrm{K}=150 \mathrm{mg}+22.5 \mathrm{mg}+150 \mathrm{mg}, \mathrm{A} 3 \mathrm{P}+\mathrm{K}=150 \mathrm{mg}+$ $22.5 \mathrm{mg}+300 \mathrm{mg}, \mathrm{A} 4: \mathrm{N}+\mathrm{P}+\mathrm{K}=150 \mathrm{mg}+22.5 \mathrm{mg}+450 \mathrm{mg}$, A5: $\mathrm{N}+\mathrm{P}+\mathrm{K}=150 \mathrm{mg}+22.5 \mathrm{mg}+600 \mathrm{mg}$ ).

\section{Parameter measurements}

According to actual condition, Net photosynthetic rate $(\mathrm{Pn})$, stomatal conductance (Gs), intercellular $\mathrm{CO}_{2}$ concentration $\left(\mathrm{C}_{\mathrm{i}}\right)$ and transpiration rate(Tr)were measured by portable photosynthesis tester (LI640002BLED) equipped with red and blue light under natural carbon dioxide concentration, and Photosynthetically active radiation intensity (PAR) was set as 800 $\mathrm{mmol} \cdot \mathrm{m}^{-2} \cdot \mathrm{s}^{-1}$. Base diameter, seedling height, leaf length, leaf width, root fresh weight and root dry weight of Phoebe bournei seedlings in each treatment group were measured. Superoxide dismutase (SOD), peroxidase (POD), catalase (CAT), malondialdehyde (MDA), soluble sugar content were measured by detached leaves of Phoebe bournei seedlings under low temperature treatment of $-2^{\circ} \mathrm{C}$ for $12 \mathrm{~h}$ (Wang et al., 2006).

\section{Statistical analysis}

Experimental data were assessed by the analysis of variance (ANOVA) and Multiple comparative analysis using the Statistical Analysis System (SAS) software. Fisher's protected least significant difference (LSD) $(p<0.05)$ was used to compare means.

\section{Results}

\section{Plant growth status of Phoebe bournei in different treatments}

Table 1 shows that base diameter, leaf length, leaf width, root fresh weight and root dry weight increased first and decreased afterwards and seedling height increased with the increase of potassium. There was no significant difference in base diameter, seedling height, leaf length and leaf width. While the root fresh weight of A4 were significantly different compared with control group (A1), and dry fresh weight of A4 were very significantly different compared with A1.

\section{Photosynthetic physiology of Phoebe bournei in different treatments}

Table 2 shows that the net photosynthetic $\operatorname{rate}(\mathrm{Pn})$, stomatal conductance (Gs), intercellular $\mathrm{CO}_{2}$ concentration $\left(\mathrm{C}_{\mathrm{i}}\right)$ and transpiration rate $(\mathrm{Tr})$ increased first and decreased afterwards with the increase of potassium. There was a very significant difference between transpiration rate, while the net photosynthetic 
rate and stomatal conductance of A4 were significantly different compared with other groups. There was significant difference in intercellular $\mathrm{CO}_{2}$ concentration between treatments.

Table 1. Plant growth status of Phoebe bournei in different treatments.

\begin{tabular}{lllllll}
\hline \multirow{2}{*}{ Treatment } & Base diameter & Plant height & Leaf length & Leaf width & $\begin{array}{l}\text { Root fresh } \\
\text { weight }\end{array}$ & Root dry weight \\
\cline { 2 - 7 } & $\mathbf{m m}$ & $\mathbf{c m}$ & $\mathbf{c m}$ & $\mathbf{c m}$ & $\mathbf{g}$ & $\mathbf{g}$ \\
\hline $\mathrm{A}_{1}$ & $4.85 \pm 0.39 \mathrm{aA}$ & $54.31 \pm 2.97 \mathrm{aA}$ & $9.87 \pm 1.83 \mathrm{aA}$ & $2.24 \pm 0.21 \mathrm{aA}$ & $6.35 \pm 0.91 \mathrm{~b} \mathrm{~A}$ & $2.67 \pm 0.20 \mathrm{cB}$ \\
$\mathrm{A}_{2}$ & $6.01 \pm 0.38 \mathrm{aA}$ & $53.36 \pm 2.75 \mathrm{aA}$ & $11.42 \pm 1.12 \mathrm{aA}$ & $2.51 \pm 0.06 \mathrm{aA}$ & $6.36 \pm 0.43 \mathrm{abA}$ & $3.04 \pm 0.29 \mathrm{bcAB}$ \\
$\mathrm{A}_{3}$ & $6.08 \pm 0.23 \mathrm{aA}$ & $59.93 \pm 5.53 \mathrm{aA}$ & $12.01 \pm 2.07 \mathrm{aA}$ & $3.12 \pm 0.19 \mathrm{aA}$ & $7.57 \pm 0.25 \mathrm{abA}$ & $3.59 \pm 0.07 \mathrm{abcAB}$ \\
$\mathrm{A}_{4}$ & $5.52 \pm 0.11 \mathrm{aA}$ & $59.87 \pm 0.74 \mathrm{aA}$ & $14.36 \pm 1.74 \mathrm{aA}$ & $3.31 \pm 0.64 \mathrm{aA}$ & $8.02 \pm 0.25 \mathrm{aA}$ & $3.87 \pm 0.31 \mathrm{aA}$ \\
$\mathrm{A}_{5}$ & $5.62 \pm 0.53 \mathrm{aA}$ & $62.37 \pm 1.35 \mathrm{aA}$ & $11.75 \pm 1.18 \mathrm{aA}$ & $2.78 \pm 0.32 \mathrm{aAB}$ & $6.53 \pm 0.61 \mathrm{abA}$ & $3.68 \pm 0.33 \mathrm{abAB}$ \\
\hline
\end{tabular}

Table 2. Photosynthetic physiology of Phoebe bournei in different treatments.

\begin{tabular}{|c|c|c|c|c|}
\hline Treatment & $\begin{array}{l}\text { Net photosynthetic rate } \\
P_{n}\end{array}$ & $\begin{array}{l}\text { Stomatal conductance } \\
\mathbf{G}_{\mathrm{s}}\end{array}$ & $\begin{array}{l}\text { Intercellular } \mathrm{CO}_{2} \text { concentration } \\
\mathrm{C}_{\mathrm{i}}\end{array}$ & $\begin{array}{l}\text { Transpiration rate } \\
T_{r}\end{array}$ \\
\hline & $\mathrm{umol} / \mathrm{m}^{2} * \mathrm{~s}$ & $\mathrm{~mol} / \mathrm{m}^{2} * \mathrm{~s}$ & $\mathrm{umol} / \mathrm{m}^{2} * \mathrm{~s}$ & $\mathbf{m m o l} / \mathrm{m}^{2} * \mathrm{~s}$ \\
\hline $\mathrm{A}_{1}$ & $2.25 \pm 0.04 \mathrm{dD}$ & $0.08 \pm 0.0003 \mathrm{dD}$ & $338.30 \pm 4.45 \mathrm{dC}$ & $0.14 \pm 0.003 \mathrm{eE}$ \\
\hline $\mathrm{A}_{2}$ & $2.96 \pm 0.01 \mathrm{cC}$ & $0.09 \pm 0.0003 \mathrm{cC}$ & $366.45 \pm 6.99 \mathrm{cB}$ & $0.28 \pm 0.008 \mathrm{dD}$ \\
\hline $\mathrm{A}_{3}$ & $3.54 \pm 0.08 \mathrm{bB}$ & $0.11 \pm 0.0006 \mathrm{bB}$ & $393.47 \pm 4.66 \mathrm{bA}$ & $0.41 \pm 0.01 \mathrm{cC}$ \\
\hline $\mathrm{A}_{4}$ & $4.72 \pm 0.02 \mathrm{aA}$ & $0.13 \pm 0.003 \mathrm{aA}$ & $398.09 \pm 3.21 \mathrm{aA}$ & $0.51 \pm 0.004 \mathrm{aA}$ \\
\hline$A_{5}$ & $2.26 \pm 0.03 \mathrm{dD}$ & $0.10 \pm 0.001 \mathrm{bB}$ & $393.59 \pm 4.55 \mathrm{abA}$ & $0.43 \pm 0.002 \mathrm{bB}$ \\
\hline
\end{tabular}

\section{Cold resistance physiology of Phoebe bournei in different treatments}

Table 3 shows that the activity of SOD, POD and CAT increased first and decreased afterwards with the increase of potassium, and the content of MDA decreased first and then increased, and the soluble sugar content increased. There was a very significant difference between the soluble sugar content. And POD of A4 were very significantly different compared with other groups. There were significant differences between SOD, MDA and CAT of A4 and other groups.

Table 3. Cold resistance physiology of Phoebe bournei in different treatments.

\begin{tabular}{llllll}
\hline \multirow{2}{*}{ Treatment } & SOD & POD & CAT & MDA & Soluble sugar content \\
\cline { 2 - 6 } & $\mathbf{U} / \mathbf{g}$ & $\mathbf{U} / \mathbf{g} * \mathbf{m i n}$ & $\mathbf{m g} / \mathbf{g} * \mathbf{m i n}$ & $\mathbf{u m o l} / \mathbf{L}$ & \% \\
\hline $\mathrm{A}_{1}$ & $6.90 \pm 0.12 \mathrm{cB}$ & $6.54 \pm 0.06 \mathrm{cC}$ & $5.98 \pm 0.15 \mathrm{cC}$ & $1.96 \pm 0.09 \mathrm{aA}$ & $0.13 \pm 0.006 \mathrm{eE}$ \\
$\mathrm{A}_{2}$ & $6.87 \pm 0.14 \mathrm{bcB}$ & $6.71 \pm 0.12 \mathrm{bcBC}$ & $6.66 \pm 0.25 \mathrm{bcBC}$ & $1.95 \pm 0.06 \mathrm{aA}$ & $0.27 \pm 0.002 \mathrm{dD}$ \\
$\mathrm{A}_{3}$ & $6.96 \pm 0.63 \mathrm{bAB}$ & $7.54 \pm 0.12 \mathrm{bB}$ & $7.03 \pm 0.15 \mathrm{bAB}$ & $1.67 \pm 0.04 \mathrm{abA}$ & $0.39 \pm 0.0006 \mathrm{cC}$ \\
$\mathrm{A}_{4}$ & $7.75 \pm 0.04 \mathrm{aA}$ & $8.50 \pm 0.31 \mathrm{aA}$ & $7.42 \pm 0.15 \mathrm{aA}$ & $1.59 \pm 0.08 \mathrm{bA}$ & $0.58 \pm 0.015 \mathrm{bB}$ \\
$\mathrm{A}_{5}$ & $7.47 \pm 0.03 \mathrm{bcB}$ & $7.03 \pm 0.25 \mathrm{bB}$ & $7.16 \pm 0.25 \mathrm{abAB}$ & $1.75 \pm 0.02 \mathrm{abA}$ & $0.69 \pm 0.003 \mathrm{aA}$ \\
\hline
\end{tabular}

\section{Discussion}

Plant morphology diversity is the comprehensive performance of the effective supply of environmental resources and the ability of plants to use resources (Wang et al., 2012). In the different potassium processing environment under the artificial setting, the differences of seedling growth that responded to potassium treatment showed the adaptation and ecological countermeasures of different habitats. In this study, the basal diameter, leaf length, leaf width, root fresh weight and root dry weight of Phoebe bournei were increased first and then decreased, and the appropriate potash fertilizer was beneficial to the basal diameter, leaf length, leaf width and root growth. Although Phoebe Nees plants are negative plant, while seedlings requires strict light condition, too high or too low will affect its growth (Ge et al., 2014). In the A4, basal diameter and seedling height does not reach the maximum, leaf length and root weight and leaf width reached the maximum. This is because that light intensity was low in test ground, potassium promoted photosynthesis and absorption of nutrients and water, and then increased leaf area and root weight, which was the preparation for later growth.

The plant physiological metabolism was affected by different fertilization conditions, and then the 
photosynthesis was affected (Song and Fei, 2013).The results showed that the optimum levels and ratios of $\mathrm{N}$, $\mathrm{P}$ and $\mathrm{K}$ could increase the stomatal conductance, net photosynthetic rate and transpiration rate and decrease the intercellular $\mathrm{CO}_{2}$ concentration of the functional leaves in the mulberry. While in this study, the net photosynthetic rate, stomatal conductance, intercellular $\mathrm{CO}_{2}$ concentration and transpiration rate of Phoebe bournei seedlings increased first and then decreased, and reached peak under A4 with the increase of potassium. This may be due to that optimum potassium is very good for regulating the stomatal conductance and transpiration rate, which could meet the $\mathrm{CO}_{2}$ requirement of photosynthesis of Phoebe bournei seedlings, and then increase the net photosynthetic rate; in addition, the excess $\mathrm{CO}_{2}$ free from the cells leads to an increase in intercellular $\mathrm{CO}_{2}$ concentration.

SOD, POD and CAT are important enzymes that protect cells against reactive oxygen species damage (Frank et al., 2001; Dong et al., 2013; Ma and Wang, 2013). SOD is an active substance derived from the living body, which can eliminate the harmful substances produced by the organism during metabolic process. The results showed that CAT and POD activities of grape variety with strong cold-resistance were high, and decreased slowly with the changes of time and temperature, while those with poor cold-resistance had low enzyme activity and decreased sharply with the changes of time and temperature (Liu et al., 2008).

The similar result has been found out in our study, when the seedlings of Phoebe bournei were exposed to low temperature, the activity of SOD, POD and CAT increased first and decreased afterwards and reached the highest level under A4 with the increase of potassium, which indicated that the appropriate potash fertilizer was beneficial to improve the activity of enzyme system for protection. When plants suffer from low temperature, the appropriate potassium can increase the soluble sugar content in the cell, thereby regulating the osmotic pressure for protecting the plant. In this study, the soluble sugar content in Phoebe bournei leaves increased with the increase of potassium, which was consistent with the results of others (Gao et al., 2015). MDA is one of the most important products of membrane lipid peroxidation, it could aggravate the damage to the cell membrane, and the content of MDA can reflect the degree of injury to the plant (Xi, 2000). Some studies have suggested that the content of MDA in plant branches showed an increased trend with the longer cooling time under low temperature stress (Yang et al., 2015). In this study, when the seedlings of Phoebe bournei were exposed to low temperature, the activity of MDA decreased first and increased afterwards and reached the lowest level under A4 with the increase of potassium, which indicated that the appropriate potash fertilizer could decrease the damage of MDA to the membrane, and then improve the cold resistance of Phoebe bournei seedlings.

\section{Conclusion}

In conclusion, the optimal potassium can promote photosynthesis and morphological growth of Phoebe bournei seedlings, and enhanced stress protection under stress. Considering the scientific fertilization principle, the optimum fertilizer ratio was $\mathrm{N}+\mathrm{P}+\mathrm{K}=150 \mathrm{mg}+$ $22.5 \mathrm{mg}+450 \mathrm{mg}(\mathrm{A} 4)$.

\section{Conflict of interest statement}

Authors declare that they have no conflict of interest.

\section{Acknowledgement}

This work was supported by the national second survey for key protected wild plant resources (special investigation for Phoebe and Machilus in Hubei Province).

\section{References}

Chu, X. L., Liu, Q. H., Fan, H. H., Wang, S. H., Chen, L. Y., Zhou, Z. C., 2014. Growth and structure differentiation of Phoebe bournei plantation with different sites and modes of afforestation. Forestry Sci. Res. 27(4), 445-453.

Dong, L., He, Y. Z., Wang, Y. L., Dong, Z. Y., 2013. Research progress on application of superoxide dismutase (SOD). Rev. China Agric. Sci. Technol. 15(5), 53-58.

Frank, V., Eva, V., James, F. D., Dirk, I., 2001. The role of active oxygen species in plant signal transduction. Plant Sci. 161(3), 405-414.

Fu, L. G., Jin, J. M., 1991. Plant red data book China. Beijing Science Press, China.

Gao, Q. Y., Wei, Y. Y., Zhao, S. L., Yan, C., Zhang, B. X., Zhang, W. J., 2015. Effects of winter natural temperature drop on cold resistant physiological indices of three species of blueberry. Hubei Agric. Sci. 52(9), 2142-2145. 
Ge, Y. J., Liu, Y. J., Gao, W., Xu, B., Gao, Y. T., Ni, R. X., 2014. Morphological responses and adaptation of seedlings of three tree species of Phoebe Nees to different light regimes. J. Jiangxi Agric. Univ. 36(1), 109-114.

Guan, A. W., Liao, X. L., Yang, M. X., Nian, Z. F., Zhao, L. F., Peng, Y., 2014. Effects of different potassium supply level on growth and potassium accumulation in tobacco seedlings. Hubei Agric. Sci. 52(9), 2024-2026.

Huang, G. Q., Zhang, L., Gao, H., Kong, F. H., Wei, L., Tong, W. H., Yin, H., Liu, G., Luo, C. H., 2012. Effect of different NPK fertilizer application level on photosynthetic characteristics of mulberry. Southwest China J. Agric. 25(6), 2173-2179.

Li, S. W., 2003. Comprehensive evaluations of various afforestation patterns Phoebe bournei. J. Jiangxi Agric. Univ. 25, 100-103.

Liu, W., Qu, L. H., Liu, H. Q., Yang, D. C., Liu, X., 2008. Effects of chilling stress on protective enzymes activities and oxygen free radical of grapes. Nor. Horticul. 5, 21-24.

Liu, Y. N., Ma, H. Y., Xian, H. M., 2015. Effects of fertilization on yield and fruit quality of pineapple. China Fruits. 5, 55-58.

Ma, Y. L., Wang, P., 2013. Effects of low temperature stress on physiological indicators of cold resistance in two species of Syringa L. J. Hebei Agric. Univ. 36(2), 54-59.

Song, G., Fei, Y. J., 2013. Effects of different formulated fertilizations on plant growth and photosynthesis of Lin-dera megaphylla. J. Yangtze Univ (Natural Science Edn). 10(11), 16-18.

Wang, D. G., Yin, G. T., Yang, J. C., Li, R. S., Zou, W. T., Jia, R. F., 2014. Effects of phosphorus fertilization on growth and foliar nutrient (N, P, K) of Phoebe bournei seedlings. J. Nanjin Fry. Univ. 38(3), 40-44.

Wang, D. G., Yin, G. T., Zou, W. T., Li, R. S., Yang, J. C., 2013. Effects of nitrogen loading on growth and photosynthetic characteristics of Phoebe bournei seedlings. Forestry Sci. Res. 26(1), 70-75.

Wang, X. K., Zhang, W. H., Hao, Z. B., 2006. Principles and techniques of plant physiology and Biochemistry Experiments. Beijing Higher Education Press, China.

Wang, Z. X., Zhu, J. M., Wang, J., Wang, Y., Lu, Y. Q. and Zheng, Q. R., 2012. The response of photosynthetic characters and biomass allocation of Phoebe bournei young trees to different light regimes. Acta Ecol. Sin. 32(12), 3842-3847.

$\mathrm{Wu}, \mathrm{D} . \mathrm{R} ., 1995$. Preliminary report on population ecology of Phoebe phoebe. Nanjing Fry. Univ.

Wu, D. R., Wang, B. S., 2001. Seed and seedling ecology of the endangered Phoebe bournei (Lauraceae). Acta Ecol. Sin. 21(11), 1751-1760.

Wu, J., Wu, D., Lou, X. Z., 2015. Effect of different substrate compositions and fertilizer formulations on 3-year-old Phoebe species container seedlings. Western Fry. Sci. 44(1), 109-113, 120.

Xi, Z. Y., Wu, K. Y., Wang, T. C., Wang, C. Y., 2000. Analysis of utilizing value of physiological and biochemical indexes of maize drought resistance identification. J. Henan Agric. Univ. 34(1), 7-12.

Yang, J., Zhu, Y. F., He, X. L., Zhang, S. J. and Zhang, Q., 2015. Effects of low temperature stress on cold resistance physiology of Viburnum sargentii Koehne and Weigela florida CV. variegata. J. Hebei Agric. Univ. 38(2), 60-65.

\section{How to cite this article:}

Zhu, S., Liu, G., 2017. Effects of potassium fertilizer on the growth and physiology of Phoebe bournei seedlings. Int. J. Curr. Res. Biosci. Plant Biol. 4(11), 24-28. doi: https://doi.org/10.20546/ijcrbp.2017.411.004 